\title{
Experimentally Induced Diabetes Mellitus Influences Expression of VEGF and CD68 in Rat Teeth Pulp
}

\author{
La Diabetes Mellitus Inducida Experimentalmente Influye en la \\ Expresión de VEGF y CD68 en la Pulpa de Dientes de Rata
}

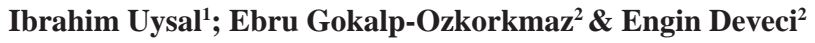

UYSAL, I.; GOKALP-OZKORKMAZ, E. \& DEVECI, E. Experimentally induced Diabetes mellitus influences expression of VEGF and CD68 in rat teeth pulp. Int. J. Morphol., 37(2):606-611, 2019.

SUMMARY: The purpose of this study was to examine the expression levels of the dental pulp to elucidate the role of Vascular Endothelial Growth Factor (VEGF) and CD68 on vascular angiogenesis, inflammation and odontoblast differentiation in the pulp tissue of diabetic rats depending on the effect of possible damage induced by diabetes. Wistar rats were used in the study, divided into two groups. Control group was fed with standard rat chow and drinking water ad libitum for 8 weeks. Single dose of streptozotocin (STZ) (55 $\mathrm{mg} / \mathrm{kg}$ ), was disolved in sodium citrate buffer and administered by intraperitoneal injection. Blood glucose concentration of rats exceeding $250 \mathrm{mg} / \mathrm{dl}$ were accepted as diabetic. Rats were sacrificed under anesthesia. Tissues were immediately dissected, fixed and embedded in paraffin and cut with a microtome then examined under light microscope. In the cross-sections of pulp tissue of diabetic group; the dilation of blood vessels besides hemorrhage and a significant increase in inflammatory cells were seen. The expression of VEGF in the blood vessel endothelial cells of the pulp was increased. VEGF showed positive reaction for degenerative odontoblast cells in the pulp. In this study, increase in VEGF and CD68 expressions in pulp tissue due to the effect of diabetes was thought to delay pulp treatment by inducing soft tissue damage and hypoxia.

KEY WORDS: VEGF; CD68; Diabetes mellitus; Teeth; Rat.

\section{INTRODUCTION}

Diabetes mellitus is a disease in which carbohydrate, protein and lipid metabolism homeostasis is inadequately regulated by the pancreatic hormone insulin, resulting in an increase in blood glucose levels (Sunil et al., 2011). Diabetes is also associated with oral complications such as tooth loss, gingivitis, periodontitis, and oral mucosa lesions (Lamster et al., 2008). Several factors may contribute to the development of periodontitis in patients with diabetes mellitus, including defective polymorphonuclear leukocyte function, altered collagen metabolism, pathological vascular change, compromised wound healing potential and microbiological imbalance (AAP, 1996). Experimental animals were used to state the possible effects of diabetes on dental caries (Nakahara et al., 2012, 2013a,b, 2014). According to a study of Bender \& Bender (2003), diabetes affects the pulp tissue directly. Claudino et al. (2015) indicated that diabetes triggers the loss of tooth structure, mediates its evolution to progressive severe pulp and periapical lesions in rats. Catanzaro et al. (2006) showed in the pulp tissue that levels of nitrite and kallikrein were altered in diabetic rats. Components of dental pulp tissue, such as vascular changes and thickened basement membrane were reported to be altered in long-term diabetes. Moreover, calcification in pulp tissue were more frequent in diabetics (Russell, 1966).

Vascular endothelial growth factor (VEGF) is a 45$\mathrm{kDa}$ heparin binding glycoprotein involved in several essential cell processes. It is a powerful endothelial cell mitogen and is involved in mediating cell differentiation, proliferation and permeability $(3,4)$ In angiogenesis, several cytokines play important roles, but the vascular endothelial growth factor (VEGF) is considered to be vital (Arras et al., 1998). CD68 is an antigenically heterogeneous molecule. Inflammatory cells in diseased soft tissues determine macrophage activity in the demonstration of cells.

In this study the effects of streptozotocin-induced diabetes on teeth pulp of rats were investigated using histopathological and immunohistochemical methods.

\footnotetext{
${ }^{1}$ Department of Endodontics, Diyarbakır Oral and Dental Health Center, Turkey.

${ }^{2}$ Dicle University Faculty of Medicine, Department of Histology and Embryology, Turkey.
} 
Therefore, purpose of this prospective study was to examine the expression levels of VEGF and CD68 in the rat dental pulp to elucidate their role on vascular angiogenesis, inflammation and odontoblast differentiation in pulp tissue depending on the possible damage of diabetes.

\section{MATERIAL AND METHOD}

Experimental procedure. The present work was conducted in accordance with the guidelines for the Care and Use of Laboratory Animals from Dicle University Experimental Animal Research Center. 20 adult male Wistar rats were randomly divided into 2 groups. Control group $(n=10)$ were fed with standard rat chow and drinking water ad libitum for 8 weeks. Diabetic group $(n=10)$ received aingle dose of STZ $(55 \mathrm{mg} / \mathrm{kg}$ ) (Sigma, USA), disolved in sodium citrate buffer $(0.1 \mathrm{M}, \mathrm{PH} 4.5)$ and administered by intraperitoneal injection (8). Before the experiment subjects were fasted for $12 \mathrm{~h}$, then fed with standard rat chow and drinking water after $4 \mathrm{~h}$. After fasting of 2 days and $12 \mathrm{~h}$, blood glucose levels were measured from the tail end with the capillary blood glucose meter (Contour TS Bayer) and value of 250 $\mathrm{mg} / \mathrm{dl}$ or above was considered as diabetic and included in the experiment.

At the end of the experimental period blood samples were taken for biochemical tests under ketamin+xylazin anesthesia injected by cardiac puncture. The animals were sacrificed by decapitation. First, the mandibular regions were dissected immediately. The molar teeth samples were fixed with neutral buffered formalin solution and decalcified with $5 \%$ ethylene-diamine tetraacetic acid. After fixation, molar teeth were directly dehydrated in a graded series of ethanol and embedded in paraffin wax. Next, 4-6 $\mu \mathrm{m}$ sections were cut with a microtome (Rotatory Microtome, Leica, RM 2265, Germany) and mounted on coated slides. The sections were stained with Trichrom masson stain and observed under light microscopy (Nikon Eclipse 80i).

Immunohistochemical staining. An antigen-retrieval process was performed in citrate buffer solution ( $\mathrm{pH}$ 6.0) two times: first for $7 \mathrm{~min}$, and then for $5 \mathrm{~min}$ in a microwave oven at $700 \mathrm{~W}$. They were allowed to cool to room temperature for $30 \mathrm{~min}$ and washed in distilled water for 5 min twice. Endogenous peroxidase activity was blocked in $0.1 \%$ hydrogen peroxide for 15 min. Ultra $\mathrm{V}$ block (Histostain-Plus Kit, Invitrogen, Carlsbad, CA) was applied for 10 min prior to the application of the primary antibodies (osteonectin antibody, mouse monoclonal, 1/200, Santa Cruz Biotechnology, or osteopontin antibody, mouse monoclonal, 1/200, Santa Cruz Biotechnology) overnight. The secondary antibody (Histostain-Plus Kit, Invitrogen, Carlsbad, CA) was applied for $20 \mathrm{~min}$. Then the slides were exposed to streptavidin-peroxidase for $20 \mathrm{~min}$. Diaminobenzidine (DAB, Invitrogen, Carlsbad) was used as a chromogen. Negative control slides were prepared as mentioned above but omitting the primary antibodies. After counterstaining with Mayer Heamatoxylene stain, washing in tap water for $5 \mathrm{~min}$, and in distilled water for $2 \times 5 \mathrm{~min}$, the slides were mounted.

Western Blot analysis (Figs. 1 and 2)

\section{Control DM}

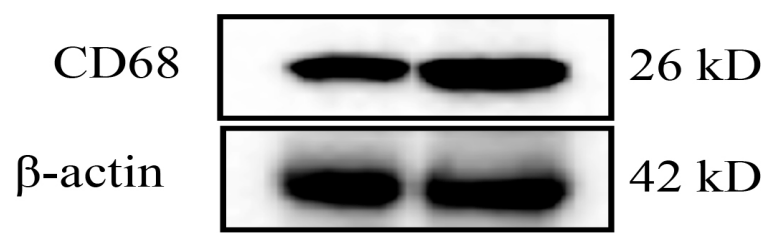

Fig. 1. The level of CD68 expression in testicular tissue was increased in the diabetes (DM) group. Equal amounts of total protein gel were run and analyzed by Western blotting using anti-CD68 and anti- $\beta$-actin antibodies. $\beta$-actin was used as loading control.

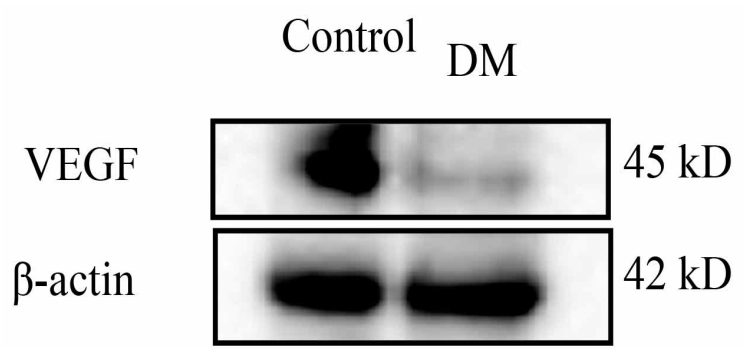

Fig. 2. The level of VEGF expression in testicular tissue was decreased in the diabetes (DM) group. Equal amounts of total protein gel were run and analyzed by Western blotting using antiVEGF and anti- $\beta$-actin antibodies. $\beta$-actin was used as loading control.

Cell lysis and protein quantification. The snap frozen bone was grinded to a fine powder in a chilled mortar in the presence of liquid nitrogen. Immediately after grinding, 50 $\mathrm{mg}$ bone powder was transferred into a microcentrifuge tube containing $250 \mu \mathrm{l}$ RIPA lysis buffer $(150 \mathrm{mM} \mathrm{NaCl}, 50 \mathrm{mM}$ Tris, $1 \mathrm{mM}$ EDTA, $1 \%$ (v/v) Triton X-100, $1 \%$ (w/v) sodium deoxycholate, $0.1 \%$ (w/v) SDS, $0.2 \%$ (w/v) sodium fluoride, $0.2 \%(\mathrm{w} / \mathrm{v})$ sodium orthovanadate and $1 \times$ protease inhibitor mixture [CompleteTM EDTA free; Roche Diagnostics]) and incubated in ice for $1 \mathrm{~h}$. After incubation, aliquots were snapfrozen in liquid nitrogen and stored in $-86^{\circ} \mathrm{C}$. All these steps were performed on ice to minimize protein degradation. Total cellular protein concentration was determined in triplicate 
using a BCA protein assay according to manufacturer's instructions (Pierce, Thermo scientific). The BCA assay was performed in a 96-well plate using MultiscanTM GO microplate from Thermo Scientific.

SDS-PAGE. All protein samples were resolved by $10 \%$ (v/ v) polyacrylamide gel using a Mini Protean Tetra Cell apparatus system (Bio-Rad). The protein samples were prepared in $1 \times$ SDS loading buffer [ $2 \%(\mathrm{w} / \mathrm{v})$ SDS, $5 \%(\mathrm{v} /$ v) glycerol, $0.01 \%(\mathrm{w} / \mathrm{v})$ bromophenol blue, $8 \%(\mathrm{w} / \mathrm{v}) \mathrm{DTT}$, which was added just before heating] and heated at $100{ }^{\circ} \mathrm{C}$ for $5 \mathrm{~min}$. They $(20 \mu \mathrm{g}$ ) were then loaded on to the $10 \%$ (v/ v) polyacrylamide gel and electrophoresed at $200 \mathrm{~V}$ for $1 \mathrm{~h}$ in a SDS running buffer [2.4 mM Tris, $19.2 \mathrm{mM}$ glycine, $0.01 \%(w / v)$ SDS].

Membrane transfer and antibody staining. Separated proteins from the SDS-PAGE were transferred onto the PVDF membrane at $100 \mathrm{~V}$ for $1 \mathrm{~h}$ in transfer buffer $[25 \mathrm{mM}$ Tris, $192 \mathrm{mM}$ glycine, $20 \%$ (v/v) methanol, $\mathrm{pH}$ 8.3] using a Criterion Blotter Transfer System (Bio Rad). The membrane was then blocked with $5 \%(\mathrm{w} / \mathrm{v})$ skim milk powder in PBS$\mathrm{T}[\mathrm{PBS}+0.1 \%(\mathrm{v} / \mathrm{v})$ Tween-20] for $1 \mathrm{~h}$ at room temperature. After blocking, the membrane was probed with primary antibodies (Anti-VEGF 1:200, Santa Cruz ; Anti-CD68 1:200,Santa Cruz and ant-b-actin 1:1000,Abcam) for $2 \mathrm{~h}$ at room temperature. The membrane was then washed four times over 30 min with PBS-T before probing with horseradish peroxidase-conjugated secondary antibodies in 1:10000 dilutions for $1 \mathrm{~h}$ at room temperature. The membrane was again washed four times over $30 \mathrm{~min}$ with PBS-T. The protein bands were visualized using ECL (Bio-Rad) according to the manufacturer's instruction. The image acquisitions were done with the ChemiDocMP Imager (BioRad).

Statistical analysis. Statistical analysis was carried out using GraphPad Prism 4.0 software (GraphPad Software, 2003, San Diego, CA, USA). All data are presented as mean \pm standard deviation (SD). Data of diabetic and control groups were compared with an analysis of variance (ANOVA) followed by Tukey's multiple comparison tests. Values of $\mathrm{p}<0.05$ were considered as statistically significant.

\section{RESULTS}

The serum glucose levels were found to be statistically significant between the two groups (Table I). The blood glucose concentration of diabetic group showed a significant increase when compared to control group ( $\mathrm{p}$ $<0.05)$.

In the cross-sections of the control group; the distribution of blood vessels, cells and collagen fibrils in pulp tissue was regular so, no evidence of dental caries was observed. However, dental caries were verified in diabetic group; revealed irregular pulp tissue and the dilation of blood vessels besides hemorrhage and a significant increase in inflammatory cells hyperplasia in odontoblast cells. Irregular distribution in collagen fibers and an increase in inflammatory cells were also observed. In the cross-sections of control group, negative CD68 expression was observed in cells surrounding small vessels and other pulp cells. Immunohistochemical labeling of antiCD68 antibody, which is specific for macrophage cells, revealed the presence of macrophages infiltrating around the blood vessels and the connective tissue in teeth pulp that have histomorphologic characteristics of degeneration. Nevertheless, there was an increase in CD68-positive cells, in inflammatory cells around blood vessels and also an increase in CD68 expression in cells showing phagocytic activity. VEGF expression in the pulp was weakly positive in perivascular fibroblasts and odontoblasts in the control group. On the other hand, an increase in VEGF expression in endothelial cells was seen as VEGF positive in odontoblast cells and inflammatory cells of the diabetic group (Fig. 3).

\section{DISCUSSION}

Diabetes is therefore described as a factor that amplifies oral complications such as xerostomia, tooth loss, gingivitis, periodontitis, and oral mucosa lesions (Lamster et al.). Moreover, teeth pulp is more prone to be at risk for

Table I. Comparison between the glucose levels of diabetic and control group

\begin{tabular}{lll}
\hline $\begin{array}{l}\text { Groups } \\
\text { Average of blood glucose concentration }(\mathrm{mg} / \mathrm{dl})\end{array}$ & $\overline{\mathrm{X}}$ & $\begin{array}{l}\text { Standard } \\
\text { deviation }(\mathrm{sd}) \pm \mathrm{sd}\end{array}$ \\
\hline $\begin{array}{l}\text { Non-diabeticgroup } \\
\text { Diabetic group }\end{array}$ & $\begin{array}{l}97,2857 \\
4,3452\end{array}$ \\
\hline
\end{tabular}

Measuring the average \pm SD and Min- Max. ANOVA analysis was performed, $\mathrm{P}<0.05$ value is statistically different from that of control group. 

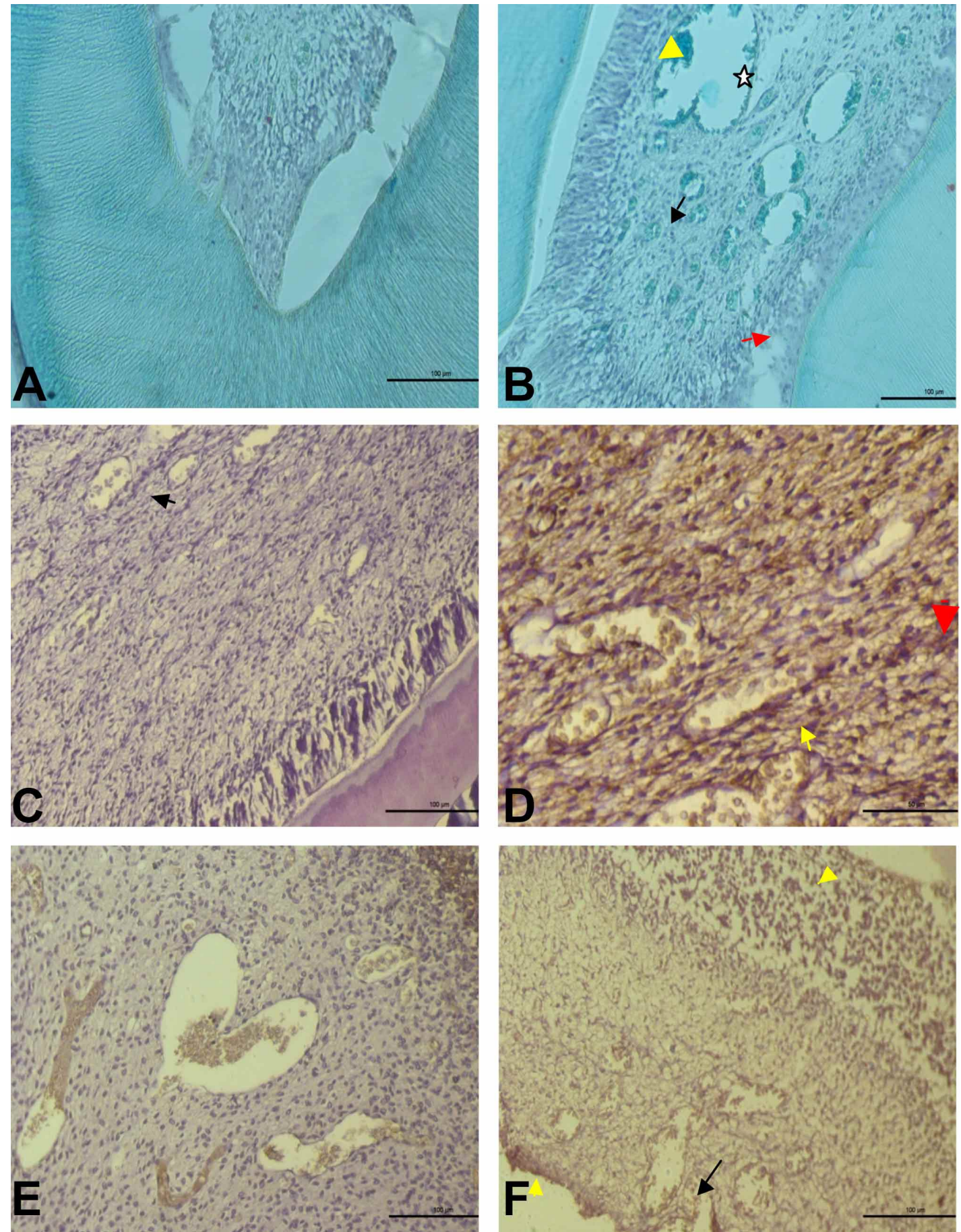

Fig. 3. A-Control group: Normal appearance of blood vessels, cell and fibrous distribution in pulp tissue Trichrommasson staining. Bar $100 \mu \mathrm{m}$. B-Diabetes group: Hemorrhage and dilation in blood vessels (star),Hyperplasia in odontoblast cells (yellow arrowhead) Irregular distribution of collagen fibrils (red arrow) An increase in inflamatory cells(arrow) Trichrom-masson staining. Bar $100 \mu \mathrm{m}$. C-Control group: Negative CD68 expression in cells surrounding small vessels and other pulp cells. CD68 immunostaining. Bar $100 \mu \mathrm{m}$. D-Diabetes group: CD68positive cells in inflammatory cells (yellow arrow) An increase in CD68 expression in cells showing phagocytic activity(red arrow) CD68 immunostaining. Bar $50 \mu \mathrm{m}$. E-Control group: Weak VEGF expression in endothelial cells and perivascular fibroblasts and odontoblasts, VEGF immunostaining. Bar $100 \mu \mathrm{m}$. F-Diabetes group: An increase in VEGF expression in endothelial cells(arrow)VEGF positive reaction in odontoblast cells and inflammatory cells(yellow arrow). VEGF immunostaining. Bar $100 \mu \mathrm{m}$. 
infection because the dental pulp has limited or no collateral circulation (Bender \& Bender). And also it is known that diabetics are particularly prone to bacterial or opportunistic infections. The spread of this infection can lead to circulatory disturbances due to the accumulation of atheromatous deposits in blood vessels and tissues and an increase in haemorrhages. Wang et al. (2011) found higher frequency of tooth extraction after endodontic therapy in patients with DM, suggesting lower success rate of root canal treatment. Supporting this findings, histological studies showed increased thickness of blood vessel basement membrane, reduction in collagen level of intercellular substance and signs of chronic inflammation and angiopathy. This vascular problems can also cause anaerobic infection, which may be depend on reduced oxygen diffusion over the blood vessel wall (Bender \& Bender). Garber et al. (2009) showed that pulp in diabetic rats had compromised reperatory response resulting in chronic pulp inflammation and reduced dentin bridge formation in comparison to pulp in non-diabetic rats . In our study diabetic group revealed irregular pulp tissue and the dilation of blood vessels besides hemorrhage has also been a significant increase in inflammatory cells. Hyperplasia in odontoblast cells and irregular distribution in collagen fibers and an increase in inflammatory cells were observed. In the present study, monocytes / macrophages and inflammatory expressions was increased in pulp tissue of diabetic rats. Oxidative stress in the dental pulp caused by diabetes has been thought to increase circulatory disturbance and inflammation. Another outcome of oxidative stress is the advanced glycation endproducts, which are free radicals resulting diabetic microangiopathy, a widespread complication caused by endothelial dysfunction (Vlassara, 1996). However, it can increase sensitivity by affecting tissue nutrition and impairing pulp metabolism. A study of Claudino et al., defined an increase of necrotic areas in pulp tissue, accompanied by a trend of increase in inflammatory cells. Our findings showed an increase in inflammatory CD68positive cells around the pulp vessels in the diabetes group supporting the idea of inflammation and as a consequence, phagocytic activity. Facchiano et al (2002) stated in their study that the presence of pulp injury involved in dental caries may lead to necrotic areas and influx of inflammatory cell.

VEGF is produced by endothelial cells, macrophages, activated T cells, and a variety of other cell types (Ferrera \& Davis-Smyth, 1997) and is of great importance for microcirculatory system of dental pulp. The expression of VEGF and its receptors has been identified in pulp using polymerase chain reaction (PCR) method (Matsushita et al., 2000; Grando Mattuella et al., 2007) as well as immunohistochemical identification (Güven et al., 2007). Increased expression of VEGF has been noticed during some pathological conditions of dental pulp such as inflammation, injury and hypoxia (Chu et al., 2004; Tran-Hungi et al., 2008; Aranha et al., 2010) but other factors can upregulate VEGF expression including the local concentrations of glucose . Our examinations revealed that the expression of VEGF in the blood vessel endothelial cells of the pulp was increased. VEGF showed positive reaction for degenerative odontoblast cells in the pulp.

It is well accepted that diabetes aggravates inflammatory responses, increasing chemotaxis and tissue damage. Our results provide strong evidence that the increase in VEGF and CD68 expressions, as indicators of inflammation, due to the effect of diabetes on the pulp was thought to delay pulp treatment by inducing soft tissue damage and hypoxiaThese result suggest that the treatment phase of diabetes will develop negatively with the increase in the expression of angiogenetic and inflammatory mediators induced after diabetic injury in the dental pulp.

UYSAL, I.; GOKALP-OZKORKMAZ, E. \& DEVECI, E. La diabetes mellitus inducida experimentalmente influye en la expresión de VEGF y CD68 en la pulpa de dientes de rata. Int. J. Morphol., 37(2):606-611, 2019.

RESUMEN: El propósito de este estudio fue examinar los niveles de expresión en la pulpa dental para dilucidar el papel del Factor de Crecimiento Endotelial Vascular (VEGF) y el CD68 en la angiogénesis, la inflamación y la diferenciación de odontoblastos en el tejido pulpar de ratas diabéticas, dependiendo del efecto de daño inducido por la diabetes. Se utilizaron ratas Wistar divididas en dos grupos. El grupocontrol se alimentó con comida estándar para ratas y agua potable ad libitum durante 8 semanas. Se administró mediante inyección intraperitoneal dosis única de estreptozotocina (STZ) $(55 \mathrm{mg} /$ $\mathrm{kg}$ ), se disolvió en tampón de citrato de sodio. La concentración de glucosa en sangre de ratas que excedían los $250 \mathrm{mg} / \mathrm{dl}$ se aceptó como diabética. Las ratas fueron sacrificadas bajo anestesia. Los tejidos se disecaron de inmediato, se fijaron en parafina y se cortaron para luego ser examinados con un microscopio óptico. En las secciones transversales del tejido pulpar del grupo diabético se observó la dilatación de los vasos sanguíneos además de hemorragia y un aumento significativo de células inflamatorias. La expresión de VEGF se incrementó en las células endoteliales de los vasos sanguíneos de la pulpa. VEGF mostró una reacción positiva para las células odontoblásticas degenerativas en la pulpa. El aumento en la expresión de VEGF y CD68 en el tejido de la pulpa debido al efecto de la diabetes puede retrasar el tratamiento de la pulpa al inducir hipoxia y daños en los tejidos blandos.

PALABRAS CLAVE: VEGF; CD68; Diabetes mellitus; Dientes; Rata. 


\section{REFERENCES}

Aranha, A. M.; Zhang, Z.; Neiva, K. G.; Costa, C. A; Hebling, J. \& Nör, J. E. Hypoxia enhances the angiogenic potential of human dental pulp cells. J. Endod., 36(10):1633-7, 2010.

Arras, M.; Ito, W. D.; Scholz, D.; Winkler, B.; Schaper, J. \& Schaper, W. Monocyte activation in angiogenesis and collateral growth in the rabbit hindlimb. J. Clin. Invest., 101(1):40-50, 1998.

Bender, I. B. \& Bender, A. B. Diabetes mellitus and the dental pulp. J. Endod., 29(6):383-9, 2003.

Chu, S. C.; Tsai, C. H.; Yang, S. F.; Huang, F. M.; Su, Y. F.; Hsieh, Y. S. $\&$ Chang, Y. C. Induction of vascular endothelial growth factor gene expression by proinflammatory cytokines in human pulp and gingival fibroblasts. J. Endod., 30(10):704-7, 2004.

Claudino, M.; Nunes, I. S.; Gennaro, G.; Cestari, T. M.; Spadella, C. T.; Garlet, G. P. \& de Assis, G. F. Diabetes triggers the loss of tooth structure associated to radiographical and histological dental changes and its evolution to progressive pulp and periapical lesions in rats. Arch. Oral Biol., 60(11):1690-8, 2015.

Ferrera, N. \& Davis-Smyth, T. The biology of vascular endothelial growth factor. Endocr. Rev., 18(1):4-25, 1997.

Garber, S. E.; Shabahang, S.; Escher, A. P. \& Torabinejad, M. The effect of hyperglycemia on pulpal healing in rats. J. Endod., 35(1):60-2, 2009.

Grando Mattuella, L.; Poli de Figueiredo, J. A.; Nör, J. E.; de Araujo, F. B. \& Medeiros Fossati, A. C. Vascular endothelial growth factor receptor-2 expression in the pulp of human primary and young permanent teeth. J. Endod., 33(12):1408-12, 2007.

Güven, G.; Altun, C.; Günhan, O.; Gurbuz, T.; Basak, F.; Akbulut, E. \& Cehreli, Z. C. Co-expression of cyclooxygenase- 2 and vascular endothelial growth factor in inflamed human pulp: an immunohistochemical study. J. Endod., 33(1):18-20, 2007.

Lamster, I. B.; Lalla, E.; Borgnakke, W. S. \& Taylor, G. W. The relationship between oral health and diabetes mellitus. J. Am. Dent. Assoc., 139 Suppl::19S-24S, 2008.

Matsushita, K.; Motani, R.; Sakuta, T.; Yamaguchi, N.; Koga, T.; Matsuo, K.; Nagaoka, S.; Abeyama, K.; Maruyama, I. \& Torii, M. The role of vascular endothelial growth factor in human dental pulp cells: induction of chemotaxis, proliferation, and differentiation and activation of the AP-1-dependent signaling pathway. J. Dent. Res., 79(8):1596-603, 2000.

Nakahara, Y.; Ozaki, K.; Sano, T.; Kodama, Y. \& Matsuura, T. Assessment of Alloxan-Induced Diabetic Rats as a Periodontal Disease Model Using a Selective Cyclooxygenase (COX)-2 Inhibitor. J. Toxicol. Pathol., 27(2):123-9, 2014.

Nakahara, Y.; Sano, T.; Kodama, Y.; Ozaki, K. \& Matsuura, T. Alloxaninduced hyperglycemia causes rapid-onset and progressive dental caries and periodontitis in F344 rats. Histol. Histopathol., 27(10):1297306, 2012

Nakahara, Y.; Sano, T.; Kodama, Y.; Ozaki, K. \& Matsuura, T. Glycemic control with insulin prevents progression of dental caries and cariesrelated periodontitis in diabetic WBN/KobSlc rats. Toxicol. Pathol., 41(5):761-9, 2013b.

Nakahara, Y.; Sano, T.; Kodama, Y.; Ozaki, K. \& Matsuura, T. The effect of food hardness on the development of dental caries in alloxaninduced diabetic rats. J. Diabetes Res., 2013:787084, 2013a.

Russell, B. G. Gingival changes in Diabetes mellitus. Acta Pathol. Microbiol. Scand., 68:161-8, 1966.

Sunil, C.; Ignacimuthu, S. \& Agastian, P. Antidiabetic effect of Symplocos cochinchinensis (Lour.) S. Moore. in type 2 diabetic rats. $J$. Ethnopharmacol., 134(2):298-304, 2011.

Tran-Hungi, L.; Laurent, P.; Camps, J. \& About I. Quantification of angiogenic growth factors released by human dental cells after injury. Arch. Oral Biol., 53(1):9-13, 2008.
Vlassara, H. Advanced glycation end-products and atherosclerosis. Ann. Med., 28(5):419-26, 1996.

Wang, C. H.; Chueh, L. H.; Chen, S. C.; Feng, Y. C.; Hsiao, C. K.\& Chiang, C. P. Impact of diabetes mellitus, hypertension, and coronary artery disease on tooth extraction after nonsurgical endodontic treatment. J Endod., 37(1):1-5, 2011.

\section{Corresponding author: \\ Ebru Gokalp-Ozkorkmaz \\ Dicle University Faculty of Medicine \\ Department of Histology and Embryology \\ Diyarbakir \\ TURKEY}

Received: 10-08-2018

Accepted: 21-09-2018

Email: ebrug76@gmail.com 